\title{
FISH CANNING WASTEWATER TREATMENT IN SEQUENCING BATCH REACTOR WITH ACTIVATED SLUDGE
}

\author{
Dijana Grgas*, Marina Ugrina* , Merima Toromanović ${ }^{* *}$, Jasmina Ibrahimpašić ${ }^{* *}$, \\ Tea Štefanac", Tibela Landeka Dragičević* \\ ${ }^{*}$ University of Zagreb, Faculty of Food Technology and Biotechnology, Zagreb, Croatia \\ ** University of Bihać, Biotechnical Faculty, Bihać, Bosnia and Herzegovina \\ corresponding author: Tibela Landeka Dragičević, e-mail: tlandekadragicevic@pbf.hr
}

This work is licensed under a

Creative Commons Attribution 4.0

Original scientific paper

International License

Received: October $24^{\text {th }}, 2019$

Accepted: January $10^{\text {th }}, 2020$

HAE- 1925

https://doi.org/10.33765/thate.10.2.1

\begin{abstract}
The biological performance of flocculent sludge in sequencing batch reactor for the treatment of fish canning wastewater was evaluated in terms of organic matter and nutrient removal by gradual increase of salt concentration in the nitritation-denitritation process. Salinity negatively affected the biological system performance in a way that reduced organic and nutrient removal. The removal efficiency of organic matter and nitrogen showed good performance below $20 \mathrm{~g} \mathrm{NaCl} / \mathrm{L}$, while phosphate accumulating organisms activity was deteriorated and declined during whole experiment. Nitrogen removal occurred as ammonium oxidation with nitrite accumulation. Nitrite reduction was not affected by salt concentration.
\end{abstract}

Keywords: fish canning wastewater, nutrient removal, organic carbon removal

\section{INTRODUCTION}

Fish processing industries generate wastewater, the amount and composition of which depend on the type of fish processed, the additives and the water source used, and the type of the operation process applied. Fish processing wastewaters are characterized by high salt (mainly sodium chloride) concentration, high levels of organic matter (up to $90000 \mathrm{mg} / \mathrm{L}$ ), high suspended solids (up to $5000 \mathrm{mg} / \mathrm{L}$ ), nitrogen $(\mathrm{N})$ (total $\mathrm{N}$ up to $3000 \mathrm{mg} / \mathrm{L}$ ) and phosphorus (P) (total $\mathrm{P}$ up to $44.2 \mathrm{mg} / \mathrm{L}$ ) and $\mathrm{pH} 3.8$ - 10 [1]. Salinity could affect biological system performance negatively, it may decline organic and nitrogen removal efficiency, and inhibit bacterial metabolism [2, 3]. Also, during rapid changes in salt concentration, the cell plasmolysis and the increase of soluble chemical oxygen demand (COD) was observed by Uygur and Kargi [4]. Biological treatment of saline wastewater requires a long acclimation process of the non-halophilic biomass to the saline environment [5]. The negative effect of salt is often associated with nitrogen removal. Some studies pointed out that the nitrite oxidizing bacteria (NOB) are more sensitive to the salt concentration than the ammonium-oxidizing bacteria (AOB) [6 - 8]. Zhao et al. [9] 
highlighted that activated sludge had good performance below $2.0 \mathrm{wt} . \%$ in the treatment of synthetic saline wastewater. Chen et al. [3] reported that at salinity ranging from 0 to 20 $\mathrm{g} / \mathrm{L}$, removal rate of ammonium $\left(\mathrm{NH}_{4}{ }^{+}-\mathrm{N}\right)$, total phosphorus (TP) and COD gradually dropped from $95.34 \%, 93.58 \%$ and $94.88 \%$ $(0 \mathrm{~g} / \mathrm{L})$ to $62.98 \%, 55.64 \%$ and $55.78 \%(20$ $\mathrm{g} / \mathrm{L})$, respectively, in synthetic wastewater. The effect of salt in synthetic wastewater containing 0 and $15 \mathrm{~g} \mathrm{NaCl} / \mathrm{L}$ on the aerobic granular sludge process in terms of granulation and nutrient removal was examined by Wang et al. [10]. $15 \mathrm{~g} / \mathrm{L} \mathrm{NaCl}$ at dissolved oxygen (DO) of $2.5 \mathrm{mg} / \mathrm{L}$ significantly affected ammonium and phosphorous removal due to inhibition of AOB and phosphorus accumulating organisms (PAOs). Increasing the DO to $8 \mathrm{mg} / \mathrm{L}$ or adapting mature granules by gradually increasing the salt concentration minimized the adverse effect of salt on nitrification. These strategies were not helpful for phosphorus removal. The effect of salt on phosphorus removal was less studied. Bassin et al. [2] showed that at high salt concentrations (22 and $33 \mathrm{~g} \mathrm{NaCl} / \mathrm{L}$ ) PAOs gradually disappeared from the sludge, and that AOB could tolerate salt concentration of up to $33 \mathrm{~g} \mathrm{NaCl} / \mathrm{L}$. Pronk et al. [7] reported that in the absence of nitrite, bio-P removal was not much affected at salt concentrations up to $22 \mathrm{~g} / \mathrm{L} \mathrm{NaCl}$, but was significantly inhibited at salt concentrations of $33 \mathrm{~g} / \mathrm{L} \mathrm{NaCl}$. Also, Pronk et al. [7] stated that NOB showed complete inhibition at $20 \mathrm{~g} \mathrm{NaCl} / \mathrm{L}$. Wan et al. [11] highlighted that full partial nitrification can be achieved under $\mathrm{NaCl}$ concentration up to $50 \mathrm{~g} \mathrm{NaCl} / \mathrm{L}$, resulted with nitrite accumulation of nearly $100 \%$.

There are several studies investigating the effect of salt on the removal efficiency of nitrogen from real fish-processing wastewaters. Figueroa et al. [12] treated fish canning effluent with salt contents of up to 30 g NaCl/L with granular sludge and achieved complete depletion of organic carbon but less than $40 \%$ nitrogen removal efficiencies. Similar results were obtained by Val del Río et al. [13]. Simultaneous nitritation-denitritation at salinities up to $50 \mathrm{~g} \mathrm{NaCl} / \mathrm{L}$ in the treatment of fish canning wastewater by aerobic granular sludge resulted in total nitrogen below 10 $\mathrm{mg} / \mathrm{L}$ in effluent [6]. Capodici et al. [14] cultivated autochthonous halophilic biomass for the treatment of real fish canning wastewater $(30 \mathrm{~g} \mathrm{NaCl} / \mathrm{L})$ by a shortcut nitrification-denitrification process and achieved more than $95 \%$ of nitrogen removal. Corsino et al. [15] evaluated the impact of increasing salinity on halophilic biomass in form of flocculent and granular sludge for the treatment of hypersaline fish canning wastewater (from 30 to $50 \mathrm{~g} / \mathrm{L}$ ). They reported that the ammonium uptake rate was slightly affected with salinity above $46 \mathrm{~g} \mathrm{NaCl} / \mathrm{L}$, while nitrite uptake rate did not show a significant connection with the increasing salinity.

The objective of this research was to study the treatment of fish canning wastewater with a gradual increase of salt concentration in order to evaluate the removal efficiency of organic matter and nitrogen in the sequencing batch reactor (SBR) with flocculent sludge. The results of this study could provide a better understanding of activated sludge performance in terms of organic and $\mathrm{N}$ removal from fishprocessing wastewaters.

\section{EXPERIMENTAL}

\section{Wastewater characterization and analytics}

Fish canning wastewater after collecting was left to settle for $2 \mathrm{~h}$. COD, $\mathrm{NH}_{4}-\mathrm{N}$, nitrate $\left(\mathrm{NO}_{3}-\mathrm{N}\right)$, nitrite $\left(\mathrm{NO}_{2}-\mathrm{N}\right)$ and $\mathrm{PO}_{4}-\mathrm{P}$ were quantified with Merck cuvette kits (Merck, Deutschland), which are analogous to the standard methods [16]. The samples were filtered through the fiberglass filter before analysis. Temperature, $\mathrm{pH}$, and DO were monitored by WTW Multi 3420 SET KS1, Germany. Fish canning wastewater was characterized with average value of $\mathrm{COD}_{\text {soluble }}$ $1380 \mathrm{mg} / \mathrm{L}, \mathrm{NH}_{4}-\mathrm{N} 72 \mathrm{mg} / \mathrm{L}, \mathrm{PO}_{4}-\mathrm{P} 32 \mathrm{mg} / \mathrm{L}$, $\mathrm{pH} 7.1 \pm 0.1$, and salt concentration $30 \mathrm{~g} / \mathrm{L}$. 


\section{Experimental set-up}

Adaptation of the activated sludge to salinity was carried out in a SBR reactor, fed with synthetic wastewater (prepared according to de Kreuk et al. [17]) and trace elements solution according to Vishniac and Santer [18] with a gradual increase in salinity from $0 \mathrm{~g} \mathrm{NaCL} / \mathrm{L}$ up to $30 \mathrm{~g} \mathrm{NaCl} / \mathrm{L}$. In experiment with no salt added the removal efficiency for $\mathrm{COD}, \mathrm{NH}_{4}-\mathrm{N}$ and $\mathrm{PO}_{4}-\mathrm{P}$ was $96 \%, 99 \%$, and $97 \%$, respectively. Also, in experiments with synthetic wastewater the activated sludge showed high metabolic activity for organic matter and nitrogen removal at salt concentration below $25 \mathrm{~g} \mathrm{NaCl} / \mathrm{L}$, while $\mathrm{PO}_{4}-\mathrm{P}$ removal significantly decreased at salinity $20 \mathrm{~g}$ $\mathrm{NaCl} / \mathrm{L}$.

Activated sludge adapted to salinity was used in the treatment of fish canning wastewater (15 $\mathrm{g} \mathrm{NaCl} / \mathrm{L}$; diluted wastewater with tap water) and with gradually increasing of salinity $(2.5 \mathrm{~g}$ $\mathrm{NaCl} / \mathrm{L}$ ) by addition of $\mathrm{NaCl}$ up to $30 \mathrm{~g} / \mathrm{L}$, in terms of organic and nutrient removal efficiency. The $\mathrm{pH}$ was not controlled, just recorded. DO concentration was maintained at $7 \mathrm{mg} / \mathrm{L}$ and the temperature was $20 \pm 2{ }^{\circ} \mathrm{C}$. A bubble diffuser provided the air supply (HIBLOW HP 40; Hagen Model40 A-10011).

\section{RESULTS AND DISCUSSION}

The wastewater from the fish canning industry is characterized by huge variations in composition due to the type of fish processed and the type of process. Fish canning produces a large amount of wastewater which contains organic pollutants, high nutrient concentrations, and high salinity (chloride) [1].

The effect of salinity to $\mathrm{COD}, \mathrm{NH}_{4}-\mathrm{N}$ and $\mathrm{PO}_{4}-\mathrm{P}$ removal efficiency from fish canning wastewater, and from synthetic wastewater without salt added is shown in Figure 1.

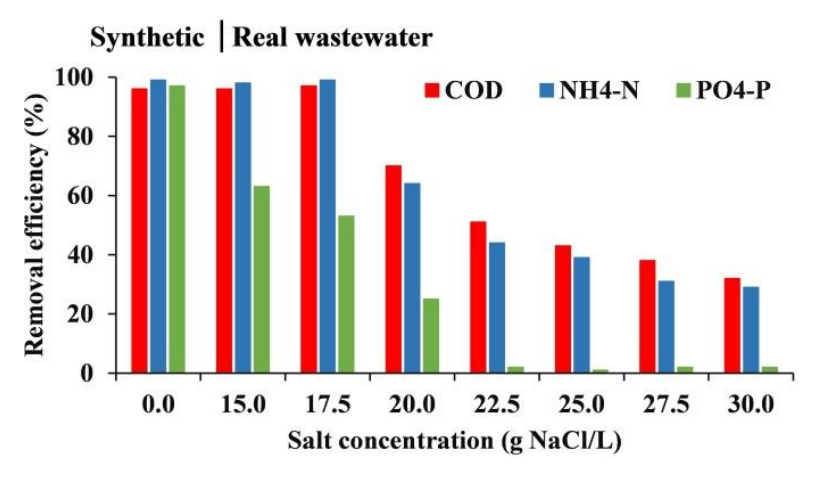

Figure 1. $\mathrm{COD}, \mathrm{NH}_{4}-\mathrm{N}$ and $\mathrm{PO}_{4}-\mathrm{P}$ removal efficiency from fish canning wastewater at different salt concentration, and from synthetic wastewater without salt added

The activated sludge maintained stable operation and high removal efficiency of $\geq 96$ $\% \quad \mathrm{COD}$ and $98 \quad \% \quad \mathrm{NH}_{4}-\mathrm{N}$ at a salt concentration below $20 \mathrm{~g} \mathrm{NaCL} / \mathrm{L}$, in the treatment of real fish canning wastewater. The salt concentration $20 \mathrm{~g} \mathrm{NaCL} / \mathrm{L}$ affected the activated sludge with $70 \%$ and $64 \%$ removal efficiency for COD and $\mathrm{NH}_{4}-\mathrm{N}$, respectively, and further decrease of $\mathrm{COD}$ and $\mathrm{NH}_{4}-\mathrm{N}$ removal efficiency was observed with the increase of salinity (Figure 1). The negative effect of salinity on the removal of organic $\mathrm{C}$ and $\mathrm{N}$ was pointed out by other authors $[3,9]$ in the treatment of synthetic wastewater.

The effect of increasing salinity in the treatment of fish canning wastewater resulted in a decrease in the removal efficiency of organic carbon and nutrients (Figure 1).

Variation in $\mathrm{COD}, \mathrm{NH}_{4}-\mathrm{N}, \mathrm{NO}_{2}-\mathrm{N}$ and $\mathrm{PO}_{4}-\mathrm{P}$ during the treatment of fish canning wastewater at $15 \mathrm{~g} \mathrm{NaCl} / \mathrm{L}$ in SBR with activated sludge is shown in Figure 2. 

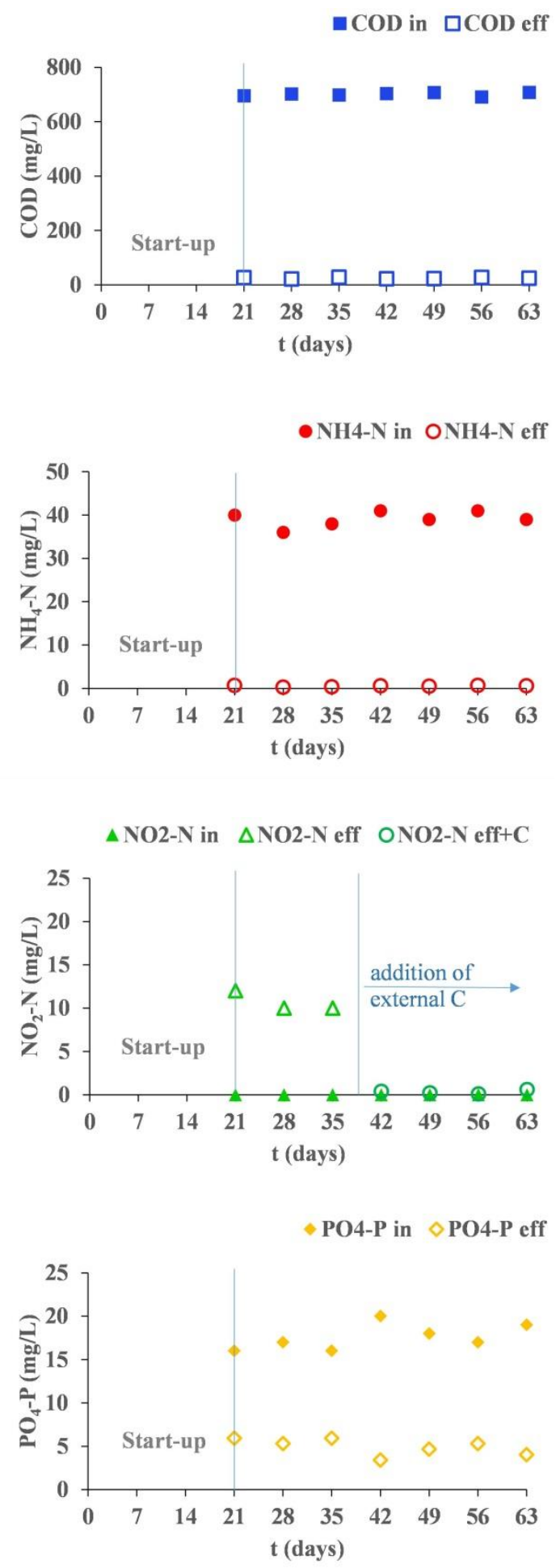

Figure 2. Influent and effluent of COD, $\mathrm{NH}_{4}-\mathrm{N}, \mathrm{NO}_{2}-\mathrm{N}$ and $\mathrm{PO}_{4}-\mathrm{P}$ during biodegradation of fish canning wastewater at salinity $15 \mathrm{~g} \mathrm{NaCl} / \mathrm{L}$ in SBR with activated sludge

At salinity of $15 \mathrm{~g} \mathrm{NaCl} / \mathrm{L}$ (Figure 2), the aerobic react stage of 11 hours resulted in constant effluent quality in terms of COD with effluent values below $30 \mathrm{mg} / \mathrm{L}$, and also with total $\mathrm{NH}_{4}-\mathrm{N}$ oxidation with $\mathrm{NO}_{2}-\mathrm{N}$ as the only product in the effluent (only nitritation occurred). No $\mathrm{NO}_{3}-\mathrm{N}$ recorded in effluent suggested the inhibition of NOB activity. At the steady state, the COD removal efficiency was equal to $96 \%$ and $\mathrm{NH}_{4}-\mathrm{N}$ to $98 \%$. During the anoxic phase (before the end of cycle) the $\mathrm{NO}_{2}-\mathrm{N}$ reduction (denitritation) was observed but not complete due to lack of organic carbon since the COD was removed at the aerobic stage, and with the use only endogenous carbon source. Complete denitritation occurred only after addition of a known amount of sodium acetate as carbon source at the beginning of anoxic phase which contributed to overall N removal. Salinity had no effect on nitrite removal. Partial nitrification is energy cost effective so this could be a good solution. Similar to our findings, the numerous studies highlighted the lack of NOB activity as more sensitive to salinity than AOB [2, $6-8,11$, 15]. Salinity deteriorated the $\mathrm{C}, \mathrm{N}$ and $\mathrm{P}$ removal (Figure 1).

Figueroa et al. [12] highlighted that in the treatment of fish canning wastewater by using granular sludge achieved complete depletion of organic carbon but less than $40 \%$ nitrogen removal efficiency with increasing salinity up to $30 \mathrm{~g} \mathrm{NaCl} / \mathrm{L}$. Also, by using autochthonous halophilic biomass in the treatment of hypersaline fish canning wastewater, Corsino et al. [15] pointed out that ammonium uptake rate was slightly affected with salinity above $46 \mathrm{~g} \mathrm{NaCl} / \mathrm{L}$, while nitrite uptake rate did not show a significant connection with the increasing salinity. Capodici et al. [14] achieved more than $95 \%$ of nitrogen removal in the treatment of real fish canning wastewater $(30 \mathrm{~g} \quad \mathrm{NaCl} / \mathrm{L})$ by shortcut nitrification-denitrification with autochthonous halophilic biomass.

In this study, the salt significantly affected phosphorus removal efficiency from $63 \%$ at $15 \mathrm{~g} \mathrm{NaCl} / \mathrm{L}$ to $25 \%$ at $20 \mathrm{~g} \mathrm{NaCl} / \mathrm{L}$, while at 22.5 up to $30 \mathrm{~g} \mathrm{NaCl} / \mathrm{L}$ removal efficiency was negligible with severely deteriorated PAOs activity (Figure 1). 
A similar effect of salt on PAOs was observed by Bassin et al. [2], Pronk et al. [7] and Wang et al. [10] who studied the effect of salinity on the treatment of synthetic wastewaters.

In this work, the experiments were conducted at DO $7 \mathrm{mg} / \mathrm{L}$ with a gradual increase in salinity (Figure 1), which are reported in the literature as favourable factors to bridge the negative effect of salinity on microbial activity $[2,6,7,10-12,15]$.

Prior to the experiments with real fish canning wastewater, the adaptation of activated sludge was performed with synthetic wastewater with gradual increase of salinity from $0-30 \mathrm{~g}$ $\mathrm{NaCl} / \mathrm{L}$. The importance of sludge adaptation to salinity was highlighted by Lefebvre and Moletta [5].

The results of $\mathrm{COD}, \mathrm{NH}_{4}-\mathrm{N}$ and $\mathrm{PO}_{4}-\mathrm{P}$ removal efficiency were $96 \%, 99 \%$, and 97 $\%$ in the treatment of synthetic wastewater with no salt added (Figure 1). High metabolic activity for organic matter and nitrogen removal in synthetic wastewater at a salt concentration below $25 \mathrm{~g} \mathrm{NaCl} / \mathrm{L}$ was recorded, while $\mathrm{PO}_{4}-\mathrm{P}$ removal significantly decreased at salinity $20 \mathrm{~g} \mathrm{NaCl} / \mathrm{L}$ (data not shown).

Some authors reported that there was not a significant effect of adaptation of the activated sludge to salt under short- and long-term salt stress [19], while others reported that the rapid shifts in salt concentrations had more adverse effects than the gradual shifts resulting in an increase of soluble COD [5]. In this research, a decreasing trend of $\mathrm{C}, \mathrm{N}$ and $\mathrm{P}$ removal with salinity increasing by using activated sludge was evident.

\section{CONCLUSION}

The effect of gradual increase of salinity on the removal efficiency of organic $\mathrm{C}$ and $\mathrm{N}$ from fish canning wastewater resulted in decline of activated sludge activity in terms of organic carbon and nutrients removal. The process was conducted as nitritationdenitritation. Nitrite reduction was not affected by salt concentration. PAOs activity was deteriorated and declined during the whole experiments.

\section{REFERENCES}

[1] P. Chowdhury, T. Viraraghavan, A. Srinivasan, Biological treatment processes for fish processing wastewater - A review, Bioresource Technology 101(2010) 2, 439-449.

[2] J.P. Bassin, M. Pronk, G. Muyzer, R. Kleerebezem, M. Dezotti, M.C.M. van Loosdrecht, Effect of elevated salt concentrations on the aerobic granular sludge process: linking microbial activity with microbial community structure, Applied and Environmental Microbiology 77(2011) 22, 7942-7953.

[3] Y. Chen, H. He, H. Liu, H. Li, G. Zeng, X. Xia, C. Yang, Effect of salinity on removal performance and activated sludge characteristics in sequencing batch reactors, Bioresource Technology 248(2018), 890-899.

[4] A. Uygur, F. Kargi, Salt inhibition on biological nutrient removal from saline wastewater in a sequencing batch reactor, Enzyme and Microbial Technology 34(2004) 3-4, 313-318.

[5] O. Lefebvre, R. Moletta, Treatment of organic pollution in industrial saline wastewater: A literature review, Water Research 40(2006) 20, 3671-3682.

[6] S.F. Corsino, M. Capodici, C. Morici, M. Torregrossa, G. Viviani, Simultaneous nitritation-denitritation for the treatment of high-strength nitrogen in hypersaline wastewater by aerobic granular sludge, Water Research 88(2016), 329-336.

[7] M. Pronk, J.P. Bassin, M.K. de Kreuk, R. Kleerebezem, M.C.M. van Loosdrecht, Evaluating the main and side effects of high salinity on aerobic granular sludge, Applied Microbiology 
and Biotechnology 98(2014) 3, 13391348.

[8] Z. She, L. Zhao, X. Zhang, C. Jin, L. Guo, S. Yang, Y. Zhao, M. Gao, Partial nitrification and denitrification in a sequencing batch reactor treating highsalinity wastewater, Chemical Engineering Journal 288(2016), 207215.

[9] Y.Y. Zhao, H.D. Park, J.H. Park, F.S. Zhang, C. Chen, X.K. Li, D. Zhao, F.B. Zhao, Effect of different salinity adaptation on the performance and microbial community in a sequencing batch reactor, Bioresource Technology 216(2016), 808-816.

[10] Z. Wang, M.C.M. van Loosdrecht, P.E. Saikaly, Gradual adaptation to salt and dissolved oxygen: Strategies to minimize adverse effect of salinity on aerobic granular sludge, Water Research 124(2017) 1, 702-712.

[11] C. Wan, X. Yang, D.J. Lee, X. Liu, S. Sun, C. Chen, Partial nitrification of wastewaters with high $\mathrm{NaCl}$ concentrations by aerobic granules in continuous-flow reactor, Bioresource Technology 152(2014), 1-6.

[12] M. Figueroa, A. Mosquera-Corral, J.L. Campos, R. Méndez, Treatments of saline wastewater in SBR aerobic granular reactors, Water Science and Technology 58(2008) 2, 479-485.

[13] A. Val del Río, M. Figueroa, A. Mosquera-Corral, J.L. Campos, R. Méndez, Stability of aerobic granular biomass treating the effluent from a seafood industry, International Journal of Environmental Research 7(2013) 2, 265276.

[14] M. Capodici, S.F. Corsino, M. Torregrossa, G. Viviani, Shortcut nitrification-denitrification by means of autochthonous halophilic biomass in an SBR treating fish-canning wastewater, Journal of Environmental Management 208(2018), 142-148.

[15] S.F. Corsino, M. Capodici, M. Torregrossa, G. Viviani, Biokinetic behaviour of autochthonous halophilic biomass at different salinity:
Comparison between activated sludge and granular sludge systems, Frontiers in Wastewater Treatment and Modelling 4(2017), 73-78.

[16] APHA, Standard Methods for the Examination of Water and Wastewater, $21^{\text {st }}$ Edition, American Public Health Association/American Water Works Association/Water Environment Federation, Washington DC, 2005.

[17] M.K. de Kreuk, J.J. Heijnen, M.C.M. van Loosdrecht, Simultaneous COD, nitrogen and phosphate removal by aerobic granular sludge, Biotechnology and Bioengineering 90(2005) 6, 761769.

[18] W. Vishniac, M. Santer, The Thiobacilli, Bacteriology Reviews 21(1957) 3, 195213.

[19] M.S. Moussa, D.U. Sumanasekera, S.H. Ibrahim, H.J. Lubberding, C.M. Hooijmans, H.J. Gijzen, M.C.M. van Loosdrecht, Long term effects of salt on activity, population structure and floc characteristics in enriched bacterial cultures of nitrifiers, Water Research 40(2006) 7, 1377-1388.

\section{Acknowledgements}

This work has been fully supported by Ministry of Science, Education and Sport: Support for scientific and artistic research (P2440). 